\title{
Practicing Servant Leadership: Analysis of Wegmans Food Market, Marriot International and Starbucks
}

\author{
Arthur M. Baldonado, Ph.D. \\ 5246 Fallen Leaf Drive, Riverview FL 33578, USA \\ *Corresponding Author: Arthur M. Baldonado, 5246 Fallen Leaf Drive, Riverview FL 33578, USA

\begin{abstract}
Servant leadership has become one of the hottest leadership topic in business today. This article depicts lessons that can be extracted from three corporations embracing servant leadership-Wegmans Food Market, Marriott International, and Starbucks. These companies have become well-known for embracing servant leadership philosophy to the fullest.
\end{abstract}

Keywords: Servant Leaders, Wegmans Food Market, Marriott International, and Starbucks

\section{INTRODUCTION}

Building community. Service to others. Stewardship. These are words associated with servant leadership and is an increasingly influential approach to leadership and management. Spears (2005), who is one of the most cited scholars in servant leadership, noted ten characteristics of servant leadership and have served as the foundation for servant leadership scholarship and conceptual frameworks. The ten servant leadership characteristics include listening, empathy, healing, awareness, persuasion, conceptualization, foresight, stewardship, commitment to the growth of people, and building community (Berger, 2014).

Wegmans Food Market, Marriott International, and Starbucks are some of the companies this author selected to extract lessons from in this article. These companies exemplified servant leadership and have consistently been cited as model for servant leadership in literature. Organizational leaders can learn from these companies and their servant leader philosophy. This author connected leadership lessons obtained from these three prominent companies with the current servant leadership theory.

The purpose of this article is to accomplish the following: 1) briefly define and review servant leadership, 2) describe Wegmans Food Market, Marriott International, and Starbucks company profiles, and 3) provide practical application of servant leadership in the workplace.

\section{SERVANT LEADERSHIP DEFINED}

Service to others is the basis of servant leadership and has emerged as one of the prominent leadership theories today. Although servant leadership has ancient and biblical origins, Robert K. Greenleaf inspired renewed interest in the subject by his essay and noted that leaders must be servant first (Carter \& Beal, 2013). The term servant leadership was coined by Greenleaf to emphasize that leadership is enacted by meeting the highest priority needs of employees first and must set aside their personal desires to those of their followers (Ozyilmaz \& Cicek, 2015). The premise of servant leadership is to serve others first and the result will be judged in the growth of followers. While Greenleaf helped ignite interest in servant leadership, he is not the originator of the practice of servant leadership (Carter \& Beal, 2013).

Servant leadership cuts across a variety of leadership theories, but is unique in the sense of its philanthropic characteristics and multi-dimensional leadership attributes encompassing situational, transformational, and personal trait dimesions of leadership. Therefore, servant leadership is much more comprehensive and include other important dimensions missing from other leadership theories (Coetzer, Bussin, \& Geldenhuys, 2017).

The resurgence of empirical and practical interest in servant leadership theory can be attributed to a movement away from traditional hierarchical leadership (pyramid model characterized by top-down 
authority structure). This traditional leadership model indicates that organizational members are expected to serve their leaders. In contrast, the inverted pyramid calls for leaders to be at the bottom of the structure where leaders serve their followers first (Washington, Sutton, \& Sauser Jr., 2014).

Greenleaf (1977) summed up servant leadership as follows:

The servant-leader is servant first - ... It begins with the natural feeling that one wants to serve, to serve first. Then conscious choice brings one to aspire to lead. He is sharply different from the person who is leader first, perhaps because of the need to assuage an unusual power drive or to acquire material possesions. For such it will be a later choice to serve-after leadership is established. The leader-first and the servant-first are two extreme types. Between them there are sharings and blends that are part of the infinite variety of human nature (p. 66).

\section{ORGANIZATIONAL BACKGROUND}

Three companies espousing servant leadership philospohy are discussed in this section-- Wegmans Food Market, Marriott International, and Starbucks.

\subsection{Wegmans Food Market}

Wegmans is a regional supermarket and family-owned company founded in 1916 by brothers Walter and John Wegman. Headquartered in Rochester NY, Wegmans employs over 48,000 workers with 2017 annual sales of $\$ 8.7$ billion. With solid leadership, Wegmans is one of the largest private companies in the U.S with over 98 stores in New York, Pennsylvania, New Jersey, Virginia, Maryland, and Massachusetts. Wegmans sets the bar high on the shopping experience and consistently garners awards and distinctions such as FORTUNE naming Wegmans to the magazine's "100 Best Companies to Work For" list, every year starting in 1998-2017 while ranking 1st in 2005 and 2nd in 2017. In 1991, President George Bush confers "The American Business Press Points of Light Award" to Wegmans Work Scholarship Connection, as an exceptional volunteer community-service program (Wegman, 2018).

Wegmans' values include caring about the well-being and success of every person; high standards/excellence are a way of life; making a difference in every community served; respecting and listening to our people; empowering their people to make decisions that improve their work and benefit our customers and company. Finally, Wegmans believes that good people, working toward common goals, can accomplish anything they set out to do (Wegmans, 2018). Anderson (2008) quoted Wegmans' philosophy in their website as God honoring organization: "What sets us apart is that we live our values every day: making a difference; empowerment; respect, caring, and high standards. It's all about what we do, not about what we say" (p. 23). Wegmans ranked \#1 on the Harris Poll 2018 Societal Return on Investment Index, which measures a company's corporate reputation for social good. According to Wegman's website, Wegmans is committed to feeding the hungry, helping young people succeed, encouraging healthy eating \& activity enriching store neighborhoods, and supporting united way initiatives. Finally, Wegmans has donated over 14.5 million pounds of food bank donations (Wegmans, 2018)

\subsection{Marriott International}

Marriott International, Inc. is a leader in the lodging industry with more than 6,700 properties worldwide and a reported annual revenue of more than $\$ 22$ billion in 2017 . Founded by J. Willard and Alice Marriott in 1927, the company is headquartered outside of Washington, D.C. in Bethesda, Maryland. In 2017, Marriott employs over 177,000 employees worldwide. Marriott continues to set the bar high as a top employer garnering numerous accolades in 2018 such as Fortune's "The 50 Best Workplaces for Parents," Comparably's "The Best Workplaces for Diversity," Indeed's "Best Places to Work for Veterans," and Fortune's "2018 Fortune 500" (Marriott International, Inc., 2019).

Marriott has five core values: 1) putting people first, 2) pursuing excellence, 3) embracing change, 4) acting with integrity and 5) serving our world. These enduring values set Marriott apart from its competition and putting an emphasis on their spirit to serve and corporate commitment of creating better places to live and work. As a result, Fortune magazine recognized Marriott in 2018 as the "World's Most Admired Companies" for its focused on the well-being of its people. Serve360 is Marriott's initiative in doing good in every direction for Marriott worldwide. In 2017, Marriott has raised more than $\$ 6.4$ million to support the Children's Miracle Network Hospitals and UNICEF (Marriott International, Inc., 2019). 


\subsection{Starbucks}

Starbucks Corporation is an American company and one of the largest coffeehouse chains in the world. Established in 1971, Starbucks operates in over 70 countries of more than 24,000 retail stores. Headquartered in Seattle Washington, Starbucks reported an annual 2017 revenue of \$24.7 billion. With solid leadership, Starbucks employs over 277,000 workers worldwide. Starbucks consistently received top accolades such as Fortune Magazine 2009-2017 "World's Most Admired Companies" and Ethisphere Institute 2007-2017 "World's Most Ethical Companies" (Starbucks, 2019). Starbucks mission is simple: to inspire and nurture the human spirit - one person, one cup, and one neighborhood at a time. Moreover, Starbucks values include 1) creating a culture of warmth and belonging, where everyone is welcome, 2) acting with courage, challenging the status quo and finding new ways to grow our company and each other, 3) being present, connecting with transparency, dignity and respect, 4) delivering our very best in all we do and holding ourselves accountable for results. Starbucks believes in striking a balance between profitability and social conscience. As a result, Starbucks Foundation was created which gave over \$13.5 million in 2011 and making 145 grants to nonprofit organizations. In 2015, employees and customers contributed over 1 million hours of community service (Starbucks, 2019). .

\section{Analysis of Wegmans Food Market, Marriott InTERnational, StarbuCKS}

Although the abovementioned corporations are unique entities, it is interesting to note their similarities relating to servant leadership:

- Person-oriented commitment

- Serving the community

- Excellence in service

This author observed that all three companies are committed to the well-being of each person. Marriott is committed to putting people first throughout their properties; Starbucks is committed to a welcoming atmosphere in their stores; and Wegmans advocates caring about the well-being and success of every person. Excellence in service is evident in all three organizations as they consistently garnered awards and accolades such as Fortune's Magazines "Best List." Finally, service to the community is salient in abovementioned companies through their charitable giving, programs, and initiatives (i.e., Marriott's Serve360 initiative).

These companies are great examples of servant leadership. Action speaks louder than words. Marriott International, Starbucks, and Wegmans Food Market are role models in servant leadership through their various programs and commitment to social good and betterment of society.

\section{Practical Application}

Servant leadership has the potential to impact important organizational processes and has been linked to increased trust in organizational leaders, greater citizenship behavior, enhanced collaboration and team effectiveness, and greater level of employee job satisfaction and commitment (Carter \& Beal, 2013). Growing and helping leaders to perfom at high levels are key for long-term success. A mentoring program geared towards servant leadership is of paramount importance. Moreover, organizations should recruit individuals who possess servant leadership characteristics, qualities, or share similar visions (Tang, Kwan, \& Zhang, 2016).

Johnson (2011) offered the following simple habits to help hone servant leadership skills among managers today:

$>$ Listen - Find meaningful ways to invite employee and client feedback daily

$>$ Appreciate-Tell employees how much they are appreciated everyday

$>$ Respect-Treat others the way you would want to be treated

$>$ Develop - Coach employees how to be a servant leader themselves

> Unleash-Let others shine through empowerment and delegation

Finally, Keith (2013) noted seven key practices that can help servant-leaders become successful: (1) Self-awareness, (2) Listening, (3) Changing the pyramid, (4) Developing your colleagues, (5) Coaching, not controlling, (6) Unleashing the energy and intelligence of others, and (7) Foresight. 
The ultimate goal of servant leadership is to make the world a better place by focusing on the employees, customers, and communities (p. 3). For instance, leaders can help develop servant leadership within the organization by participating in community volunteer program (i.e., soup kitchen or food bank). Leading by example is vitally important to effective leadership.

\section{CONCLuSion}

Leadership is all about influencing others to action and setting a positive example. To that note, servant leadership is action-oriented and often relies on service to others, empathy, and commitment to collaboration. Servant leadership seems well suited to providing employees with the empowerment and participatory job characteristics that are related to both employee and customer satisfaction (Melchar \& Bosco, 2010). Overall, research suggests that investing in servant leadership contributes to desirable employee attitudes, behaviors, and psychological climates at work (Ozyilmaz \& Cicek, 2015). Organizations should devote resources to the development of servant leadership.

\section{REFERENCES}

[1] Anderson, J. (2008). The writings of Robert K. Greenleaf: An interpretive analysis and the future of servant leadership. Retrieved from https://www.regent.edu/acad/global/publications/sl_proceedings/2008/ anderson.pdf

[2] Berger, T. A. (2014). Servant leadership 2.0: A call for strong theory. Retrieved from http://search. proquest.com/openview/2a1cb0120e59955ca3033045dc1bccdf/1.pdf?pq-origsite=gscholar

[3] Boden, T. W. (2014). The first shall be last: The essence of servant-leadership. The Journal of Medical Practice Management. 378-9.

[4] Carter III, J. J., \& Beal, B. D. (2013). Servant leadership in multigenerational family firms. The Journal of Applied Management and Entrepreneurship, 20(4), 25-47.

[5] Coetzer, M. F., Bussin, M., \& Geldenhuys, M. (2017). The functions of a servant leader. Administrative Sciences, 7(1), 5. doi:http://dx.doi.org.proxy-library.ashford.edu/10.3390/admsci7010005

[6] Das, V. T., Rao, R. S., \& Reddy, S. A. (2014). Servant leadership: A comparative study of private and public sector companies. Sumedha Journal of Management, 3(4), 126-139. Retrieved from https://searchproquest-com.proxy-library.ashford.edu/docview/1658370468? accountid=32521

[7] Greenleaf, R. K. (1977). Servant leadership: A journey into the nature of legitimate power and greatness. Mahwah, NJ: Paulist Press.

[8] Johnson, E. (2011). How to become a servant leader. Retrieved from http://www.success.com/article/howto-become-a-servant-leader

[9] Keith, K. M. (2013). Growing to greatness through servant leadership. Retrieved from http://toserve first.com/pdfs/Growing-to-Greatness\%20through-Servant-Leadership.pdf

[10] Ljungholm, D. P. (2016). EFFECTIVE SERVANT LEADERSHIP BEHAVIOR IN ORGANIZATIONS. Linguistic and Philosophical Investigations, 15, 239-245. Retrieved from https://search-proquest-com. proxy-library.ashford.edu/docview/1790675412? accountid=32521

[11] Marion, M. (2017). All companies can embrace a servant-leader mentality. Rural Telecommunications, 36(3), 40-41. Retrieved from https://search-proquest-com.proxy-library.ashford.edu/docview/196511 7297 ? accountid $=32521$

[12] Marques, J. F. (2007). On impassioned leadership: A comparison between leaders from divergent walks of life. International Journal of Leadership Studies, 3(1), 98-125.

[13] Marriott International, Inc. (2019). Retrieved from https://www.marriott.com/marriott/aboutmarriott.mi

[14] Melchar, D. E., \& Bosco, S. M. (2010). Achieving high organization performance through servant leadership. The Journal of Business Inquiry, 9(1), 74-88.

[15] Minner, W. (2015). Leading global organization. Journal of Managment Policy and Practice, 16(2), $122-126$.

[16] Ozyilmaz, A., \& Cicek, S. S. (2015). How does servant leadership affect employee attitudes, behaviors, and psychological climates in a for-profit organizational context. Journal of Management \& Organization, 21(3), 263-290.

[17] Schmincke, D., \& Miller, E. (2016). Why servant leaders make the best leaders. Retrieved from http://www.smartceo.com/schmincke-miller-servant-leaders-

[18] Schwantes, M. (2015). Servant Leadership: The case for the best leadership philosophy. Retrieved from https: //www.hr.com/en/magazines/all_articles/servant-leadership-the-case-for-the-best-leadershi_i943 350 8. html

[19] Smale, T. (n.d.). Servant leadership and how its 6 main principles can boost the success of your startup. Retrieved from https://www.entrepreneur.com/article/307923 
[20] Spears, L. C. (2009). Servant leadership. Leadership Excellence, 26(5), 20. Retrieved from https://searchproquest-com.proxy-library.ashford.edu/docview/204513095 accountid=32521

[21] Starbucks. (2019). Retrieved from https://www.starbucks.com/about-us/company-information

[22] Tang, G., Kwan, H. K., \& Zhang, D. (2016). Work-family effects of servant leadership: The roles of emotional exhaustion and personal learning. J. Business Ethics, 137, 285-297.

[23] Wang, G., \& Hackett, R. D. (2016). Conceptualization and measurement of virtuous leadership: Doing well by doing good. J. Bus Ethics, 137, 321-345.

[24] Washington, R. R., Sutton, C. D., \& Sauser Jr., W. I. (2014). How distinct is servant leadership theory? Empirical comparisons with competing theories. Journal of Leadership, Accountability and Ethics, 11(1), 11-25.

[25] Wegmans. (2018). Retrieved from https://www.wegmans.com/about-us/company-overview.html

[26] Winston, B., \& Fields, D. (2015). Seeking and measuring the essential behaviors of servant leadership. Leadership \& Organization Development Journal, (36)4, 413-434.

Citation: Arthur M. Baldonado. " Practicing Servant Leadership: Analysis of Wegmans Food Market, Marriot International and Starbucks " International Journal of Managerial Studies and Research (IJMSR), vol 7, no. 1, 2019, pp. 34-38. doi: http://dx.doi.org/10.20431/2349-0349.0701004.

Copyright: (C) 2019 Authors. This is an open-access article distributed under the terms of the Creative Commons Attribution License, which permits unrestricted use, distribution, and reproduction in any medium, provided the original author and source are credited. 